\title{
2. Etapy realizacji projektu budowy portalu do wymiany informacji handlowej na rynku palet
}

\author{
Michał Droś*
}

\subsection{Inicjacja projektu}

Pomysł stworzenia portalu powstał w 2008 r., jednak po wstępnych analizach kosztów i czasu potrzebnego do jego realizacji został on odłożony na kolejny rok kalendarzowy. Powrócił w listopadzie 2009 r.

Pomimo działań Polskiego Komitetu Narodowego EPAL, zmierzajacych do uregulowania rynku palet EUR oraz poprawy jakości palet znajdujących się w obrocie, a co za tym idzie - bezpieczeństwa we wszystkich rodzajach działalności, gdzie wykorzystuje się palety EUR, uznano za konieczne stworzenie narzędzia umożliwiającego skuteczne ograniczenie czarnego rynku paletowego. Narzędzie to skupiałoby w jednym, wirtualnym miejscu wszystkie przedsiębiorstwa zrzeszone w PKN EPAL oraz użytkowników palet EUR. Miejscem tym ma być portal internetowy, który umożliwi firmom zajmującym się produkcją i naprawianiem palet EUR dodawanie ogłoszeń o oferowanych produktach i usługach, natomiast ich użytkownikom da możliwość szybkiego nawiązania bezpośredniego kontaktu z dostawcami wspomnianych produktów.

Główne korzyści płynące z realizacji projektu budowy portalu to:

- ograniczenie czarnego rynku paletowego w Polsce,

- zmniejszenie kosztów i skrócenie czasu poszukiwania najbliższego i najbardziej odpowiedniego dostawcy palet EUR,

- zwiększenie obrotów członków PKN EPAL,

- ograniczenie rozwoju podobnych portali, które nie gwarantuja legalności produktów,

- dostarczenie informacji o rynku paletowym poprzez gromadzenie danych, m.in. o ilościach produktów oferowanych w ogłoszeniach na portalu.

* Lic. Michał Droś - Katedra Logistyki, Wydział Zarządzania Uniwersytetu Łódzkiego, ul. Matejki 22/26, 90-237 Łódź. 
Oprócz korzyści dla całego rynku palet EUR w Polsce, zidentyfikowano również negatywne efekty zaniechania realizacji projektu:

- konieczność ponoszenia coraz większych nakładów na walkę z czarnym rynkiem paletowym w Polsce,

- poszukiwanie przez użytkowników palet EUR alternatywnych nośników transportowych, a co za tym idzie - kurczenie się rynku palet EUR,

- rozwój podobnych portali (np. www.gieldapaletowa.pl) niegwarantujących legalności produktów.

By można było przedstawić inicjatywę stworzenia portalu organom decyzyjnym PKN EPAL, należało przeprowadzić również analizę kosztów i czasu realizacji projektu. Ze względu na konieczność zachowania tajemnicy, w niniejszym rozdziale nie zostana przedstawione analizy kosztów projektu, jednak zdaniem jego inicjatora, pozwalaja one na skuteczną realizację projektu. W celu wyliczenia przybliżonych kosztów realizacji projektu, jego inicjator zwrócił się z zapytaniem ofertowym do trzech firm informatycznych. Otrzymane oferty pozwoliły określić ramy kosztowe i czasowe projektu. Według szacunków jego realizacja powinna trwać od 3 do 5 miesięcy.

W listopadzie 2009 r. inicjatywa stworzenia portalu wraz z przedstawieniem jego całościowej koncepcji została zgłoszona prezesowi PKN EPAL Romanowi Malickiemu. Po obejrzeniu prezentacji (rys. 3) i wysłuchaniu inicjatora projektu, prezes PKN EPAL postanowił przedstawić tę inicjatywę na forum Zarządu PKN EPAL. Zarząd wyraził duże zainteresowanie projektem i podjał decyzję o jego dalszych analizach. Stwierdzono, iż proponowany portal jest konieczny dla poprawy rynku paletowego w Polsce i stworzy bardzo duże możliwości rozwoju członków PKN EPAL. Sprawdzono również możliwości finansowania projektu. Ustalono, iż koszt stworzenia portalu zostanie pokryty ze środków PKN EPAL z budżetu na rok 2010. 31 grudnia 2010 r. przekazano projekt do realizacji.

\subsection{Planowanie realizacji projektu}

Po przyjęciu projektu do realizacji kierownik projektu stworzył jego opis, uwzględniający szczegółową charakterystykę zasobów potrzebnych do jego wykonania, przeprowadzając jednocześnie jego analizę pod kątem wykluczania się celów i założeń. Podczas tworzenia opisu projektu określił prawdopodobnych członków zespołu projektowego, do których zwrócił się z zapytaniem, czy byliby zainteresowani współpra- 


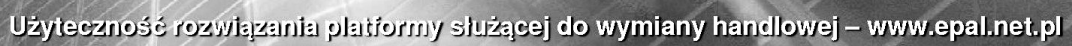

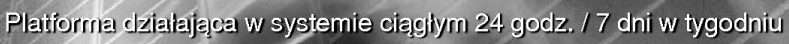

Moz̈liyość pracy dowolnej liczby użytikowników jednocześnie

Zaktaskiki ternatyczne

Palety nowe

Palely uzywane

Gititer Boxy

Neprawy palet

Riecykslinis

Elerneniy de produksji palet (drewno naturalne, drewno rozdrobnione, elenenty zlączne)

Masszyriy, urzẹjzzeria i fiarzę̧gzia

Logowanie sile? poprцez stironę internetową

Kontaki dokonyyyany bezpośrednio na stronie internetowej (komunikatior)

Możliwośc zarnieszczania oiert bezposrednio przez uzythowników

Automatyczrie przesylinie zamieszczanych oferi of zainieresowanysh podmiotów

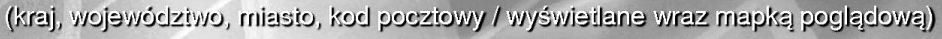

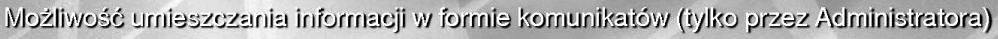

Możliyość zearrieszczarria reklarn i ogioszeni (nie nas sironie gióynej)

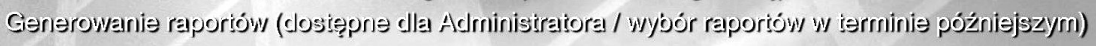

Rysunek 3. Strona prezentacji użyteczności platformy www.epal.net.pl

Źródło: opracowanie własne

ca. Były to osoby, z którymi już miał okazję z powodzeniem współpracować, co zwiększało prawdopodobieństwo sukcesu. Wstępnie zadeklarowały one chęć udziału w projekcie. Następnie zostały zidentyfikowane obszary ryzyka niepowodzenia projektu. Dzięki znajomości rynku paletowego, dużemu doświadczeniu w realizacji różnego rodzaju projektów, zaufaniu do przyszłych członków zespołu oraz wcześniejszemu uzyskaniu ofert realizacji przedsięwzięcia od trzech firm informatycznych, a także akceptacji kosztów przez właściciela projektu, kierownik mógł ograniczyć ryzyko niepowodzenia realizacji projektu do aspektów związanych z terminami. Wychodząc temu problemowi naprzeciw, zaplanował na początek stworzenie mało szczegółowego harmonogramu prac, zakreślającego tylko ramy czasowe realizacji. Szczegółowy harmonogram miał być określony dopiero po zebraniu opinii wszystkich członków zespołu realizującego projekt. Po wskazaniu i porównaniu wszystkich korzyści wynikajacych z realizacji projektu oraz nakładów finansowych i potrzebnego czasu, kierownik przeszedł do sprecyzowania mierzalnych wymagań oraz celów dotyczących czasu i kosztów. Określone zostały wskaźniki dla czasu (informujące o stopniu realizacji projektu w czasie) oraz dla kosztów (informujące o poziomie wykorzystanych zasobów finansowych). Kierownik projektu założył wskazanie poziomu bezpieczeństwa oraz poziomu alarmowego po ostatecznym 
wyborze członków zespołu i uzyskaniu koniecznych do tego informacji. Przekroczenie tych poziomów miało być sygnałem do podjęcia działań korygujących. Na podstawie zebranych danych stworzył wstępny harmonogram określający ramy czasowe i plan działań zmierzających do rozpoczęcia realizacji projektu.

Zgodnie z planem rozpoczęto prace nad organizacją zespołu projektowego. Według wcześniejszych założeń, w jego skład mieli wejść nie tylko specjaliści IT, lecz także dwie młode osoby sprawnie poruszajace się w nowoczesnym świecie Internetu, które mogłyby pomóc zaprojektować portal w taki sposób, by korzystanie z niego nie sprawiało trudności i by umożliwiał on szybki dostęp do całej gamy funkcjonalności. Osoby te miałyby niejako „bronić" tego, co jest istotne dla użytkowników, przed tym, co chcieliby zrobić informatycy. Niestety, zwyczajowa praktyką zarówno przy tworzeniu stron WWW, jak też w innych projektach IT, np. przy wdrażaniu systemów wspomagających zarządzanie, jest naleganie przez specjalistów IT na wprowadzenie rozwiązań, które sa z ich punktu widzenia prostsze do wykonania lub bardziej kosztowne, ale nie zawsze przydatne dla użytkownika końcowego. Tu kierownik zwrócił się z prośba o pomoc do opiekuna Koła Naukowego Logistyki "Uni-Logistics”, dr. Remigiusza Kozłowskiego, a on wskazał Michała Drosia i Mariusza Poprawskiego jako dwóch studentów bardzo dobrze orientujących się $\mathrm{w}$ funkcjonowaniu stron WWW oraz osoby kreatywne i komunikatywne. Jego zdaniem ci członkowie Koła "Uni-Logistics" najlepiej nadawali się do realizacji tego typu projektu. Oczekiwania wobec nich, cele projektu oraz plan pierwszych spotkań zespołu projektowego zostały im przedstawione na spotkaniu, które odbyło się 16 stycznia 2010 r. w pokoju Zakładu Logistyki na Wydziale Zarządzania Uniwersytetu Łódzkiego. Studenci wyrazili zgodę na udział w projekcie. Firma informatyczna została wybrana przez kierownika projektu przede wszystkim na podstawie wcześniejszej udanej współpracy z nim przy wykonaniu stron internetowych www.epal.org.pl i www.interconsulting.pl. Ustalenia dotyczące kosztów związanych z udziałem firmy w projekcie oraz kosztów sprzętu przez nią dostarczanego odbywały się głównie droga elektroniczną i telefoniczna. Po rekrutacji wszystkich planowanych uczestników zespołu projektowego wyłoniła się struktura organizacyjna projektu, która z punktu widzenia PKN EPAL - jego właściciela - jest typowa struktura projektu zleconego do realizacji przedsiębiorstwu zewnętrznemu (rys. 4). 


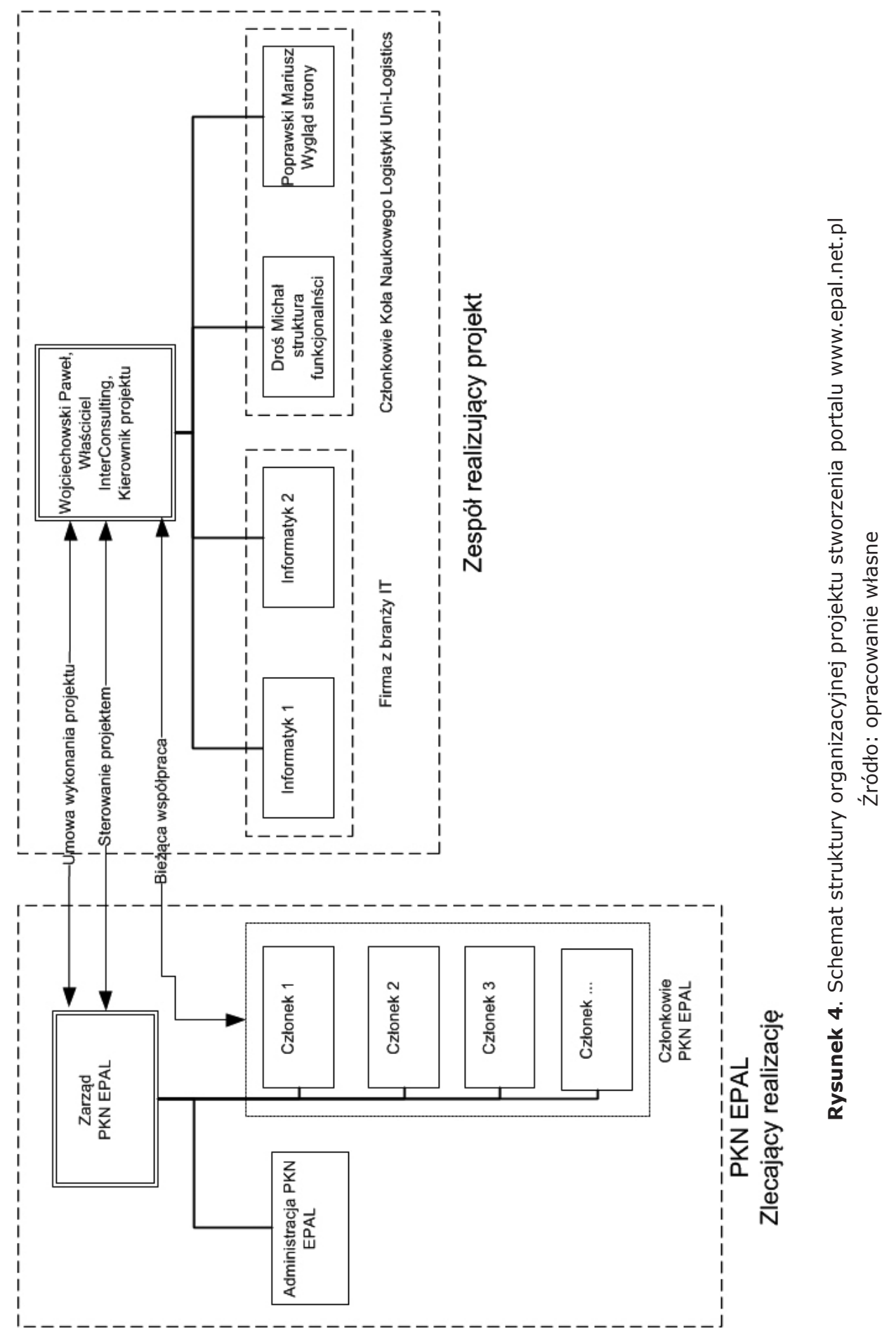




\subsection{Realizacja projektu}

Po zakończeniu wszystkich faz związanych z planowaniem projektu i zebraniem grupy projektowej nastapiła jego realizacja. Pierwsze spotkania robocze zespołu realizującego projekt odbywały się z udziałem kierownika projektu i studentów ${ }^{1}$. Każde ze spotkań, zgodnie z wytycznymi, miało składać się z następujących etapów: przedstawienie efektów prac, dyskusja i ustalenia, podsumowanie i wyznaczenie celów na następne spotkanie.

Podczas pierwszego ze spotkań roboczych, które odbyło się 16 stycznia 2010 r. o 8:00 i trwało ok. godziny, podzielono pracę między studentów i szczegółowo omówiono aspekty powierzonych im zadań, a także przedstawiono cele, które maja być zrealizowane do następnego spotkania. Zgodnie z ustaleniami Michał Droś był odpowiedzialny za opracowanie koncepcji funkcjonalnej portalu, tj. jego struktury funkcjonalności, natomiast Mariusz Poprawski miał opracować koncepcję wizualną strony, tj. zaprojektować układ elementów na stronie i jej kolorystykę.

Pierwsze efekty prac studentów zostały zaprezentowane na drugim spotkaniu roboczym, 20 stycznia 2010 r. Mariusz Poprawski przedstawił koncepcję szaty graficznej opartej na kolorystyce i układzie oficjalnej strony internetowej PKN EPAL - www.epal.org. $\mathrm{pl}^{2}$. Zastosowanie takiego układu i schematu pozwoliło wyjść naprzeciw przyzwyczajeniom użytkowników, którzy znali oficjalną stronę PKN EPAL oraz zwiększało prawdopodobieństwo kojarzenia marki EPAL z zastosowana kolorystyka, co ma bardzo duże znaczenie z punktu widzenia marketingu. Mariusz Poprawski zaproponował również dwie koncepcje układu elementów w głównej, środkowej części strony. Pierwsza dzieliła stronę o szerokości 800 pikseli $^{3}$ na trzy części, tzw. ramki, gdzie lewa i prawa ramka miałyby mieć szerokość po 150 pikseli, a w nich znalazłyby się menu użytkownika oraz menu funkcjonalności. Środkowa ramka miałaby mieć szerokość 500 pikseli i wyświetlać główną zawartość strony, w zależności od wybranej funkcjonalności. Druga koncepcja ukła-

${ }^{1}$ Byli to uczestnicy zespołu projektowego - Michał Droś i Mariusz Poprawski.

2 Nagłówek strony, górne menu, stopka strony.

${ }^{3}$ Większość stron internetowych jest przystosowana do minimalnej rozdzielczości, jaką obecnie stosuje się w ustawieniach ekranu komputera, tj. $800 \times 600$ pikseli, dzięki czemu strona jest prawidłowo wyświetlana na starych komputerach, nieobsługujących wyższych rozdzielczości ekranu. 
du strony zaproponowana przez studenta było podzielenie strony na dwie ramki, przy czym szerokość lewej wynosiłaby 200 pikseli i miałaby ona zawierać w swej górnej części menu użytkownika, a poniżej menu funkcjonalności, tj. dodawania i przeglądania ogłoszeń. Druga ramka, zajmująca pozostała część strony, miałaby mieć szerokość 600 pikseli i wyświetlać główna treść strony, w zależności od wybranego odsyłacza. Zastosowanie ramek pozwala na zdefiniowanie obszarów strony o stałych rozmiarach i przypisanie im stałego miejsca na stronie. Zazwyczaj w mniejszych ramkach umieszcza się odsyłacze do treści wyświetlanej w większych ramkach. Rozwiązanie to znacznie polepsza ergonomię strony internetowej oraz przyspiesza i ułatwia nawigowanie. Ponadto w momencie przewijania strony przesuwa się tylko treść głównej, dużej ramki, a zawartość małych ramek pozostaje bez zmian, co pozwala na łatwiejsze poruszanie się po stronie internetowej zawierajacej treści większe niż wysokość ekranu. Pozostałym uczestnikom spotkania znacznie bardziej spodobała się druga propozycja, dzieląca stronę na dwie ramki. Przedstawiona wizualizacja wydawała się znacznie bardziej czytelna i ergonomiczna. Decyzja kierownika projektu została ona wybrana do realizacji. Drugi student, Michał Droś, zaproponował koncepcję zawartości strony i układ jej następujących elementów: formularz rejestracji, wizytówka użytkownika, formularz dodawania ogłoszenia. W dalszej części spotkania kierownik projektu zgłosił swoje zastrzeżenia do zaproponowanych przez studentów rozwiązań i odbyła się dyskusja nad zmianami oraz dalszymi pracami. Na koniec podsumowano spotkanie i ustalono cele na następne.

Trzecie zebranie zespołu, jeszcze bez udziału informatyków, odbyło się 22 stycznia 2010 r. Rozpoczęło się od przedstawienia przez Michała Drosia efektów zmian jego wcześniejszych propozycji zgodnie z ustaleniami oraz zaproponowania układu i zawartości kolejnych elementów strony, tj. szczegółów ogłoszeń, zestawienia danych pokazywanych na liście wyszukiwanych ogłoszeń, sposobów filtrowania i wyszukiwania ogłoszeń. Mariusz Poprawski zaprezentował projekt graficzny całości strony, w którym każda z podstron portalu tworzyła oddzielny plik graficzny. Projekt ten nie uwzględniał na razie szczegółów zawartości ramek, ze względu na konieczność wcześniejszego ukończenia prac przez drugiego studenta. Po prezentacji prac odbyła się dyskusja nad przedstawionymi projektami oraz wprowadzanie poprawek. Część z nich była nanoszona przez obydwóch Panów na bieżąco. Po dyskusji podsumowano przebieg spotkania i wyznaczono cele na następne zebranie zespołu, 
które tym razem miało się odbyć już z udziałem informatyków, a zatem do tego czasu powinny zostać ukończone wszystkie prace nad koncepcja wizualną i funkcjonalna portalu.

Pierwsze z cyklu czterech spotkań roboczych, w których uczestniczył pełny skład zespołu realizującego projekt, odbyło się 23 stycznia 2010 r. Rozpoczęło się ono od przedstawienia efektów prac studentów i kierownika projektu pozostałym członkom zespołu. Informatycy zgłosili swoje uwagi wynikające z ograniczeń technologicznych oraz problemy mogace się pojawić przy tworzeniu strony, które zostały natychmiast omówione, co skutkowało ustaleniem alternatywnych rozwiązań. Następnie podsumowano zebranie i wyznaczono cele na następne. Studenci mieli nanieść ostatnie poprawki na stworzone przez nich dokumenty i przesłać je jak najszybciej poczta elektroniczna do kierownika projektu, tak aby informatycy mogli wykonać portal. Na zakończenie spotkania ustalono harmonogram prac nad projektem. Każdy z członków zespołu mógł wyrazić swoja opinię i zgłosić zastrzeżenia co do omawianych terminów. Po spotkaniu harmonogram całego projektu, uzupełniony o ustalenia kierownika projektu z Zarządem PKN EPAL, został przesłany do całego zespołu realizującego projekt (rys. 5).

Dalsze prace nad projektem przebiegające według przedstawionego na rys. 5 harmonogramu, opierały się głównie na pracy informatyków. Studenci wzięli udział w spotkaniach, które odbyły się 8, 12 i 19 lutego 2010 r., na których zgłaszali swoje zastrzeżenia co do efektów pracy informatyków. Ponadto, na pierwszym ze wspomnianych spotkań

Szanowni Panowie

Serdecznie dziękuję za wczorajsze spotkanie, według mnie całkiem owocne i zdecydowanie udane.

Chciałbym przesłać ustalenia ze spotkania, głównie te dotyczące terminów:

- 16 stycznia - oficjalny start projektu

- 22 stycznia - zakończenie pracy koncepcyjnej, przekazanie ustaleń do programistów

- 8 lutego - spotkanie robocze z programistami

- 12 lutego - prezentacja programistów, przekazanie poprawek

- 19 lutego - prezentacja programistów, zatwierdzenie poprawek

- 24 lutego - prezentacja InterConsulting dla PKN Epal (Ukraina)

- 1 marca - prezentacja InterConsulting, przekazanie poprawek

- 5 marca - prezentacja programistów, zatwierdzenie poprawek

- 8 marca - prezentacja InterConsulting dla PKN Epal (Polska)

- 15 marca - uruchomienie Platformy

W niniejszej wiadomości przesyłam także plik z zasadami funkcjonalności, a pod koniec weekendu prześlę także zakończone prace p. Mariusza i Michała.

Rysunek 5. Treść wiadomości zawierającej harmonogram prac nad projektem Źródło: wiadomość e-mail od kierownika projektu z dn. 23 stycznia 2010 r. 
zrodził się pomysł stworzenia funkcji Czat ${ }^{4}$ - dodatkowej funkcjonalności ułatwiającej komunikację, którego autorem był kierownik projektu. Pomysł ten został wdrożony przez informatyków i zaprezentowany 12 lutego 2010 r. Zastosowany w tej funkcjonalności układ okna i sposób jej działania zostały zaakceptowane przez wszystkich członków zespołu. Dodatkowo określono sposób wyboru i prezentacji dostępności użytkownika, z którym chce się porozmawiać przy użyciu funkcji Czat oraz ostatecznie określono sposób wybierania ogłoszeń, na które chce się wysłać wiadomość e-mail.

Kolejne spotkania odbywały się bez udziału studentów i polegały przede wszystkim na prezentacji portalu przez kierownika projektu i/lub informatyków przed PKN EPAL, podczas których były zgłaszane drobne uwagi dotyczące przede wszystkim dodatkowych funkcjonalności, takich jak np. zamieszczanie reklam w portalu oraz opcje dodawania zdjęć i dowolnych plików przez pełnoprawnych użytkowników, jak również ograniczenia możliwości użytkowników zwyczajnych.

23 stycznia 2010 r. kierownik projektu przesłał wiadomość elektroniczną do członków zespołu, proponując im uczestnictwo w spotkaniu nieuwzględnionym wcześniej $w$ harmonogramie prac. Miało się ono odbyć 22 lutego 2010 r. w Warszawie. Zaplanowano na nim prezentację projektu przed Zarządem Głównym EPAL. Stwarzało to szansę na przekonanie uczestników spotkania o konieczności nadania portalowi międzynarodowego wymiaru, aby skupiał on firmy ze wszystkich krajów członkowskich European Pallets Associacion. W spotkaniu, oprócz kierownika projektu, reprezentantów Zarządu Głównego EPAL i przedstawicieli zrzeszonych w EPAL firm z Niemiec, Austrii, Holandii, Wielkiej Brytanii, wzięli udział studenci uczestniczący w projekcie oraz dwie studentki, członkinie Koła Naukowego Logistyki „Uni-Logistics” - Magdalena Drzewoszewska i Magdalena Maciaszek. Zespół wspólnie zaprezentował funkcjonalność portalu. Kierownik projektu przedstawił korzyści płynące z jego stworzenia. Niestety, na spotkaniu zabrakło informatyków, którzy w tym czasie wciaż pracowali nad ukończeniem portalu. Po prezentacji odbyła się trwająca około czterech godzin merytoryczna dyskusja uczestników spotkania, na której omówiono sprawy związane portalem, jak również poruszono bardzo istotne kwestie dotyczące międzynarodowego obrotu paletowego i obrotu paletowego w krajach, które posiadaja komitety narodowe EPAL. Zdecydowana większość wy-

${ }^{4}$ Czat (z ang. chat - rozmowa), używana jest również angielska pisownia: chat rodzaj internetowej pogawędki i jedna z usług internetowych, za: http://pl.wikipedia.org/ wiki/Czat [z dn. 28.11.2012]. 
rażanych opinii pokrywała się z poglądami reprezentantów zespołu realizującego projekt, a wszystkie pojawiające się zarzuty podważające sens tworzenia portalu zostały odparte przez kierownika projektu merytorycznymi argumentami. Ustalono, że jeśli polska wersja portalu odniesie sukces i zostana zrealizowane postawione przed nią cele, stworzy się wersję międzynarodową portalu, w trzech językach: angielskim, francuskim i niemieckim. Zredagowano także regulamin korzystania z portalu, który jednocześnie będzie informował użytkowników o jego przeznaczeniu, jak również definiował prawa i obowiązki użytkowników oraz administratora portalu.

Równolegle do wszystkich prac i działań związanych z tworzeniem portalu, przez cały czas trwania projektu odbywały się prace nad uruchomieniem serwera, na którym miał zostać zainstalowany portal. Brali w tym udział informatycy oraz kierownik projektu. Mimo zakończenia prac nad tworzeniem portalu jako strony internetowej przed 8 marca 2010 r., tj. zgodnie $z$ harmonogramem, portal został uruchomiony dopiero 6 kwietnia 2010 r. Przełożenie terminu uruchomienia portalu wynikało z konieczności podjęcia działań promocyjnych jeszcze przed jego uruchomieniem. Obejmowały one rozesłanie wiadomości elektronicznych z informacja o jego powstaniu bezpośrednio do potencjalnych użytkowników portalu, tj. zarówno użytkowników palet EUR, jak również firm zrzeszonych w PKN EPAL.

\subsection{Ocena i zakończenie projektu}

Projekt został zakończony z dniem uruchomienia portalu, tj. 6 kwietnia 2010 r. Nastapiła tylko jedna zmiana w harmonogramie - terminu uruchomienia portalu, która była spowodowana koniecznościa podjęcia akcji marketingowej, wymaganej przez właściciela projektu. Poza nią kierownik projektu nie dopuścił do żadnych innych przesunięć w czasie, umiejętnie mobilizując członków zespołu realizującego projekt i przypominając im o „ustalonym podziale ról i zadań"5. Zgodnie z opinią wyrażoną w publikacji Zarządzanie ryzykiem projektu: „Menedżer projektu ponosi odpowiedzialność za zjednoczenie zespołu i utrzymanie go w tym stanie" ${ }^{\prime \prime}$, co w ocenie autora udało się kierownikowi projektu.

${ }^{5}$ S. Berkun, Sztuka zarządzania projektami, Helion, Gliwice 2006, s. 269.

${ }^{6}$ Y. Y. Chong, E. M. Brown, Zarządzanie ryzykiem projektu, Oficyna Ekonomiczna, Kraków 2001, s. 180. 
Jednocześnie zachował on kolejność etapów realizacji projektu zgodną z teoria zarządzania projektami, co niewatpliwie przyczyniło się do zakończenia projektu sukcesem. W opisie realizacji projektu daje się zauważyć wiele elementów, które z powodzeniem moga zostać określone jako dobre praktyki, takie jak np. przebieg spotkań zespołu realizującego projekt. Każde ze spotkań składało się z następujących elementów:

1) prezentacja efektów prac,

2) dyskusja, zgłoszenie zastrzeżeń i pomysłów,

3) podsumowanie i ustalenie celów na kolejne spotkanie.

Równie dobrym przykładem jest rozsyłanie wiadomości e-mail potwierdzających przyjęte ustalenia po każdym ze spotkań do wszystkich ich uczestników.

Po zakończeniu prac przez informatyków i zamieszczeniu portalu na serwerze sporządzono dokument stwierdzający oficjalne zakończenie projektu, który został przekazany, wraz z uruchomieniem portalu, na ręce właściciela projektu - PKN EPAL.

\subsection{Podsumowanie}

Analiza zrealizowanego przedsięwzięcia, jakim była budowa portalu do wymiany informacji handlowej www.epal.net.pl pokazuje, że projekty - zgodnie z założeniami teorii o zarządzaniu projektami - składają się z etapów, które tworzą fazy cyklu życia projektu, a ukończenie jednej pozwala na rozpoczęcie prac kolejnej fazy. Uniknięcie błędów we wczesnych fazach projektu jest możliwe tylko dzięki umiejętnemu planowaniu i odpowiedniemu kierowaniu wdrażanymi działaniami, co przyczynia się do osiagnnięcia sukcesu poprzez ograniczenie ryzyka w późniejszych etapach realizacji.

Przedstawione $\mathrm{w}$ niniejszym rozdziale przedsięwzięcie doskonale obrazuje to, jak istotna jest identyfikacja wszelkich ograniczeń w realizacji projektu, wyznaczenie celów oraz parametrów jego realizacji. Równie ważne jest dobranie odpowiedniego zespołu wykonującego projekt i zaplanowanie jego działań oraz kierowanie nim. Analiza etapów realizowanego projektu potwierdza również, że liczy się zaplanowanie odpowiedniej struktury organizacyjnej zespołu i umieszczenie go w organizacji, która jest właścicielem projektu, tak by realizacja projektu nie wpływała negatywnie na bieżąca działalność. 
Mnogość rozwiązań, które moga być stosowane w praktyce zarzadzania projektami i coraz większa popularność stawiania czoła wyzwaniom obecnych czasów poprzez realizację innowacyjnych przedsięwzięć za pomoca projektów pozwalają prognozować, że nauka o zarządzaniu projektami będzie ewoluowała, prowadząc do coraz lepszego poznania projektów i ich optymalizacji. 